\title{
LITERATURAS DE VANGUARDA: A RECEPÇÃO EM XEQUE
}

\author{
Sérgio Massucci CALDERARO
}

\begin{abstract}
RESUMO
As vanguardas, sabemos, têm entre seus principais pilares os objetivos de provocar e questionar. Essa razão de ser chega às vezes a tais extremos que pode comprometer, no caso das vanguardas literárias, o próprio ato da leitura e a formação de sentido tal qual estamos acostumados a efetuar. No entanto, seja como for, sempre haverá sentidos possíveis a serem concretizados na mente do leitor atento. Este artigo buscará desvendar os tortuosos caminhos que levam o receptor à formação de sentido no contexto de algumas das mais experimentais literaturas de vanguarda: o Dadaísmo e a Poesia Concreta. Para isso, teremos que analisar o que ocorre com o signo linguístico no ambiente vanguardista em seu contato com o leitor, apoiando-nos sempre em conceitos da Teoria da Recepção da Literatura e da Teoria do Efeito Estético
\end{abstract}

PALAVRAS-CHAVE: Vanguardas Literárias; Teoria da Recepção da Literatura; Teoria do Efeito Estético.

\section{LITERARY VANGUARDS: THE RECEPTION IN CHECK}

\section{ABSTRACT}

The Vanguards, as we know, have among their main pillars the aims of provoking and questioning. This modus operandi sometimes reaches extremes, in the case of Literary Vanguards that may jeopardize the act of reading and the construction of meaning themselves, the way we are used to do. Meanwhile, nonetheless, there will always be posible meanings to concretize in the mind of the attentive reader. This article will search for unraveling the torturous ways that lead the receptor to build meaning in the context of some of the most experimental Vanguard Literature forms: Dadaism and Concrete Poetry. Therefore, we will have to analyse what happens with the linguistic sign in the avant-garde environment, when interacting with the reader, always based on concepts of the Reception and Aesthetic Theories.

KEYWORDS: Literary avant-gardes; Literary Vanguards; Reception Theory; Aesthetic Theory.

\section{LITERATURAS DE VANGUARDIA: LA RECEPCIÓN EN JAQUE}

\section{RESUMEN}

Las vanguardias, como sabemos, tienen entre sus principales pilares los objetivos de provocar y cuestionar. Ese modus operandi llega a veces a tales extremos que puede comprometer, en el caso de las vanguardias literarias, el propio acto de la lectura y la formación de sentido tal y como estamos acostumbrados a efectuar. Sin embargo, sea como fuere, siempre habrá sentidos posibles a concretar en la mente del lector atento. Este artículo buscará desentrañar los tortuosos caminos que llevan el receptor a la formación de sentido en el contexto de algunas de las más experimentales literaturas de vanguardia: el Dadaísmo y la Poesía Concreta. Para ello, tendremos que analizar qué ocurre con el signo lingüistico en el ambiente vanguardista en su contacto con el lector, apoyándonos siempre en conceptos de la Teoría de la Recepción de la Literatura y de la Teoría del Efecto Estético.

PALABRAS-CLAVE: Vanguardias Literarias; Teoría de la Recepción de la Literatura; Teoría del Efecto Estético.






\section{CONSIDERAÇÕES GERAIS SOBRE A RECEPÇÃO DE UMA PEÇA DADAÍSTA}

Como ler um poema construído de forma pouco convencional, que utiliza signos que muitas vezes nem mesmo linguísticos podem ser considerados? Como se dá a recepção de peças poéticas que priorizam a composição espacial, gráfica e sonora em detrimento da semântica? Essa leitura mista - linguística, visual e sonora -, que derruba a primazia do semântico para destacar a informação estética, coloca em xeque a recepção leitora, ao mesmo tempo em que abre um vasto campo de possibilidades para a formação de sentido.

Nesses contextos vanguardistas, o significante, trabalhado pelas talentosas mãos do poeta, pode passar a ter significados que não necessariamente terão a ver com aqueles previstos no contrato linguístico de uma comunidade que compartilha um mesmo código idiomático.

Tais experimentos - e aqui nos referiremos principalmente ao Dadaísmo e à Poesia Concreta - criam um novo universo de signos que colocam em xeque a apreensão e a formação de sentido. A recepção é mais trabalhosa, mas pode gerar frutos surpreendentes na mente leitora. Em nossa opinião, é aí que reside a grande riqueza desses movimentos vanguardistas: as obras derivadas dessas vanguardas estão mais que abertas - estão escancaradas! - à participação leitora; mais do que exigir o aporte receptor, elas suplicam por um leitor de boa vontade que esteja disposto a entrar no jogo proposto pelo texto. Mais do que poemas, as peças dessas vanguardas podem ser consideradas exatamente isso: propostas. Quem não as aceita desvia o olhar e segue sua vida normalmente. Quem as aceita entra em uma brincadeira semiótica com inúmeras possibilidades de final.

Comecemos pelo Dadaísmo que, cronologicamente, é a primeira das duas escolas das quais nos ocuparemos neste artigo (surge oficialmente em 1916, em Zurique). Não nos estenderemos na história ou no contexto social desse movimento, mas temos que tecer algumas palavras sobre suas principais propostas ideológicas e estéticas. O Dadaísmo, desde o princípio, pretendeu ser uma anti-literatura. $\mathrm{O}$ próprio nome "Dadá", dizia Tristan Tzara, não significa nada. Ou seja, trata-se de um significante sem significado, artifício que utilizarão extensamente essa e outras vanguardas para negar a função corriqueira da unidade mais cara ao poeta: a palavra. Ao operar essa transgressão, o vanguardista aniquila o processo de recepção tradicional e propõe 


\section{KARAWANE}

jolifanto bambla ô falli bambla

grossiga m'pfa habla horem

égiga goramen

higo bloiko russula huju

hollaka hollala

anlogo bung

blago bung

blago bung

bosso fataka

นี

schampa wulla wussa ólobo

hej tatta gôrem

eschige zunbada

wulubu ssubudiu uluw ssubudu

tumba ba- umf

kusagauma

ba - umf

1 Figura 1: Hugo Ball. Extraído de

https://www.lifeder.com/poemas-del-dada-

ismo/ (consultado em 12/09/2019) 
2 Tradução ao português realizada pelo autor deste artigo.
O signo linguístico, em seu uso mundano, seria entediante, avesso a aventuras, uma "ideia estancada em um atoleiro dourado" (TORRE, 1965$, p. 322) $)^{2}$, já que sempre traz, previamente e necessariamente, um significado colado ao significante. Por que teria que ser assim? Não seria possível trabalhar a palavra em sua faceta puramente estética (espacial, visual e sonora)? Vejamos esse poema do dadaísta Hugo Ball ${ }^{1}$ (Figura 1).

Ball, nesse poema de 1917, trabalha, sobretudo, com a segunda articulação da linguagem, combinando as unidades foneticamente distintivas sem, porém, ultrapassar o limiar que levaria à constituição plena da primeira articulação. Quer dizer, a primeira articulação da linguagem fica aparentemente comprometida ou - talvez melhor dito fica mais aberta à participação do leitor. A liberdade para a constituição da primeira articulação é enorme e não está sujeita às amarras convencionais. Cada monema formado não chega propriamente a ser uma unidade significativa. Esse fato certamente modificará, em grande medida, a recepção desse tipo de poema quando comparado a um poema construído a partir de signos linguísticos completos e correntes entre certa comunidade leitora. Um poema como Karawane inaugura signos inexistentes até então. Pode-se considerar o poema inteiro como um grande ponto de indeterminação, aguardando a recepção leitora que procederá à formação de sentido. Vemos aqui duas possibilidades iniciais de leitura que gostaríamos de comentar. Uma delas operaria a recepção palavra a palavra; outra, da peça poética como um todo.

$\mathrm{Na}$ primeira alternativa, a recepção do signo linguístico poderia dar-se por uma proximidade fonética que sugerisse ao leitor alguma possibilidade de relação da palavra dadaísta com algum significante de seu repertório. O primeiro verso, por exemplo, poderia gerar na mente leitora do receptor nativo em português algo como "o elefante bambaleia", o que poderia fazer, retroativamente, com que a concretização do título da obra, Karawane, se dirigisse ao nome de um circo ou ao nome do próprio elefante que bambaleia e, a partir daí, fosse realizada a concretização de todo o poema dentro dessa temática. Essa é uma das hipóteses de senda receptora: converter os significantes sem significado imediato em significantes que ganham significado por proximidade fonética.

O segundo caminho vislumbra a recepção da peça integral. Há que se considerar aqui, logicamente, as diferentes tipografias (que nunca se repetem) utilizadas em sua composição. Elas podem ser recebidas 
como distintas vozes. Uma das possíveis concretizações originadas dessas diversas vozes tipográficas é a da ideia de completo caos. Para essa concretização contribuiria a impossibilidade imediata de qualquer conexão de significados aos significantes aí dispostos. O leitor de boa vontade voltará uma e outra vez ao poema, na tentativa de formação de sentido, já que buscar sentido em tudo o que os cercam é algo natural nos seres racionais. Essa busca de sentido objetivo estará em xeque na recepção de Karawane, e cabe a possibilidade de que nunca chegue a concretizar-se. O caminho receptivo, aí, deveria talvez ser outro: o da fruição estética.

Tudo isso são hipóteses. Sabemos que a recepção da literatura deve ter um enfoque grupal, em detrimento de olhares individuais. Esses grupos ou comunidades de leitores devem ser formados a partir de recortes sociais, históricos, culturais, etários e geográficos, conformando círculos de leitores que, influenciados por sua situação extra-texto, tenderiam a realizar a recepção de determinada obra de uma ou outra maneira. A própria produção da obra em si (ou do "artefato", para usar um termo de Jan Mukarovsky) está também condicionada por fatores extra-obra, como podem ser o cânone literário da época da produção, o gosto leitor predominante, o mercado editorial e o público consumidor.

A seguir, comentaremos os pontos que acabamos de mencionar, aplicados aos nossos objetos de estudo. Voltaremos ao poema Karawane e proporemos mais adiante uma peça da Poesia Concreta.

\section{O HORIZONTE DE EXPECTATIVAS PARA OS POEMAS DADAÍSTAS E CONCRETOS}

Como dizíamos, é preciso fechar o enfoque analítico em um grupo. Pode ser prudente, para o espaço deste artigo, trabalharmos com um público receptor bastante palpável: o atual. Podemos fechar mais ainda o foco imaginando leitores da classe média de grandes cidades brasileiras (São Paulo ou Manaus, por exemplo), que tiveram acesso à educação formal, incluindo o nível universitário. Feito o sucinto recorte, a primeira premissa possível é que, ao se deparar com o poema Karawane, o grupo, ainda que não tenha conhecimentos literários específicos, identificará que se trata de uma peça vanguardista - mesmo que não lhe venha à mente o termo "vanguarda", ele provavelmente saberá que se trata de um experimento literário. É com 
essa expectativa que, deduzimos, nosso receptor iniciará a leitura.

Pincelemos o outro lado da moeda: o horizonte de produção de Karawane (e de outras obras vanguardistas da mesma época). Eram anos convulsos em uma Europa revolucionária e belicista. A Revolução Industrial, iniciada há mais de um século, despejava, com cada vez mais intensidade e frequência, seus produtos tecnológicos no seio das urbes (carros e elevadores, só para citar dois exemplos). As capas sociais mais jovens das capitais europeias viviam o frenesi dessas inovações que pareciam encurtar o tempo e o espaço. Já se viam esgotados os modelos literários realistas e também os simbolistas. Demandavam-se novas linguagens, mais de acordo com aqueles tempos.

Dentro desse horizonte surgiram os movimentos de vanguarda de princípios do século XX e apareceram peças como Karawane. Agora, o que nos interessa notar é como se dá essa fusão de horizontes - o do nosso leitor atual de classe média de grandes cidades brasileiras e o do momento de produção das peças vanguardistas do começo do século passado na Europa.

Coincidentemente, vivemos outra vez uma época de grande atividade tecnológica, com mudanças inegáveis nas formas de transmissão da informação. O modo de se comunicar se encontra em pleno câmbio, parecendo encurtar, outra vez, o tempo e o espaço. Isso pode favorecer, nos dias de hoje, uma recepção simpática das antigas peças vanguardistas. O choque diante de Karawane pode ser diminuído por dois motivos: um deles é que o receptor se encontra dentro de um horizonte que vive a transformação da linguagem. Tanto a produção quanto a recepção de textos estão se ajustando ao canal de comunicação que mais cresce atualmente: o meio digital. Basta pensar em termos como "vc" e "tb", que parecem prescindir da segunda articulação da linguagem, restringindo-se à primeira. "Vc" e "tb" não podem ser propriamente lidos foneticamente, embora tenham, sem dúvida, seus respectivos significados colados a esses novos significantes; o outro é que, como vimos, nosso receptor tem o conhecimento necessário para identificar a obra de vanguarda e saber que vai entrar em uma peça poética que propõe justamente a experimentação.

Se considerarmos o conceito de distância estética tal qual nos expõe Jauss (1971, p. 77):

VOL. 16 | N.2 | DEZ.2019 ISSN 1415-7950
O espaço entre o horizonte de expectativas preexistente e a aparição de uma nova obra, cuja recepção pode pressupor uma mudança de horizonte ao rejeitar as experiências familiares ou conscientizar sobre as que 
se manifestam pela primeira vez, essa distância estética pode se materializar historicamente nas escala das relações do público e do julgamento da crítica (sucesso espontâneo, rejeição ou escândalo, aprovação isolada, compreensão lenta ou tardia). ${ }^{3}$

Acreditamos ser possível afirmar que ela é menor nos dias de hoje do que na época da publicação do poema fônico dadaísta Karawane, o que seria um ponto favorável à recepção dessa peça pelo grupo de leitores descrito acima. É importante considerar que, ainda que o dadaísmo já estivesse em andamento quando do lançamento do poema, Karawane foi um dos primeiros experimentos fônicos do movimento. Nossa suspeita é a de que, mesmo vivendo um ambiente já vanguardista, o leitor do início do século XX talvez não tivesse a mais mínima expectativa de se deparar com tal experimentação fônica. Ao contrário, a expectativa atual - passadas as vanguardas históricas, as vanguardas pós-guerra dos anos 1940, 1950 e 1960 e o início da revolução comunicativa e informativa que hoje vivemos - parece estar mais apta a receber um poema como Karawane. A rejeição e o estranhamento seriam menores hoje do que na época de sua produção. Essa constatação, no entanto, não isenta a problemática receptiva dos poemas fônicos atualmente. O simples fato de lançar à mente leitora uma sequência de significantes sem significado imediato é suficiente para colocar em xeque a recepção. Um dos responsáveis por essa problemática, pensamos, é o modelo tradicional de leitura que o próprio sistema de ensino fomenta, ao considerar o texto como um simples veículo de informação semântica. Acreditamos que essa dinâmica poderia começar a ser revertida - ou pelo menos equilibrada - se o ensino da literatura partisse de pressupostos também estéticos.

Saltemos agora aos anos 1950, época das vanguardas do pósguerra, entre elas a da Poesia Concreta, que questionava a unidade formal do verso tradicional, dando ênfase ao espaço gráfico como agente estrutural do poema. Entre as diversas influências explicitadas no manifesto da Poesia Concreta, figuram os dadaístas e o escritor francês Guillaume Apollinaire (1918). É de Apollinaire a proposta de que é preciso que nossa inteligência se habitue a compreender sintético-ideograficamente, em vez de analítico-discursivamente, ideia crucial para a compreensão de várias vanguardas literárias. Embora existissem outros focos de poesia concreta pelo mundo (principalmente na Europa), o ponto de maior irradiação das ideias concretistas foi
3 Tradução ao português realizada pelo autor deste artigo.

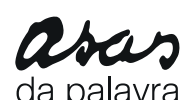

da palavra 
curiosamente o Brasil, país periférico no panorama literário mundial. O Brasil da época vivia um momento de euforia cultural, sendo a bossanova, o Cinema Novo, a construção de Brasília e o Grupo Frente de artistas plásticos como Lygia Clark, Helio Oiticica e Lygia Pape - alguns exemplos dessa efervescência. Em São Paulo, os poetas do Grupo Noigandres (Augusto de Campos, Décio Pignatari e Haroldo de Campos) elaboravam a sólida estrutura teórica da Poesia Concreta e começavam a dar à luz as primeiras obras do movimento.

A recepção inicial gerou críticas negativas, obviamente. No entanto, a novidade era tão bem estruturada que, à esperada rejeição do início, seguiu-se a formação de um crescente público adepto, que recebia positivamente os poemas concretos conectando-os com o ambiente de modernidade e ruptura que vivia o país, e motivados também pela boa aceitação internacional da Poesia Concreta brasileira. A expectativa de boa parte dos círculos leitores da época - círculos sempre reduzidos, diga-se de passagem - era justamente a de uma poesia que quebrasse com a monotonia formal da chamada Geração de 45 e que estivesse mais de acordo com o momento eufórico do Brasil de então. Por isso a Poesia Concreta cresceu e floresceu muito mais do que, por exemplo, o próprio dadaísmo em sua época. Se retomarmos agora a circunscrição de público já esboçada neste artigo para o poema dadaísta (leitores atuais de capitais e zonas urbanas brasileiras, com nível universitário), pode-se deduzir, com alguma margem de erro, que a poesia concreta brasileira continua sendo bem recebida, ora como exemplo de transgressão, ora como simplesmente um orgulho nacional. A grande produção digital atual de poetas da era cibernética influenciados explicitamente pela Poesia Concreta pode contribuir para corroborar o que estamos dizendo. E, só para voltar rapidamente ao conceito de distância estética, julgamos que, no caso da Poesia Concreta brasileira, se observaria, em linhas gerais, uma equivalência dessa distância entre os leitores dos anos 50 e os atuais.

De todo modo, estamos longe de reconstruir mais solidamente os horizontes de expectativa comentados nos últimos parágrafos. Para tal tarefa, nos faltaria exaustiva busca de documentação que pudesse confirmar nossas suposições. Mesmo assim, julgamos serem suficientes as anotações feitas até aqui nesse sentido. $\mathrm{O}$ intuito foi o de projetar o leitor deste artigo nos momentos de produção das peças poéticas VOL. 16 | N.2 | DEZ.2019 vanguardistas e, também, localizá-lo em dois momentos de recepção, 
o atual e aquele ocorrido na própria época de produção/lançamento das obras.

Não estaria bem terminar este pequeno capítulo sem o exemplo de um poema concreto, com o qual seguiremos trabalhando até o fim deste artigo. Escolhemos "beba coca cola" (Figura 2)4, de Décio Pignatari (1957):

Até aqui, vínhamos tecendo anotações sobre o horizonte de expectativas advindo do ambiente histórico, cultural e literário de determinadas épocas. Queremos agora entrar na análise da expectativa do receptor dentro da própria obra, acrescentando um plano interno intraliterário - a esse outro já citado, mais externo. Sobre a importância da abordagem desses dois planos, comenta Iser (1996, Vol. 1, p. 178):

\begin{abstract}
A relação entre primeiro e segundo planos é a condição central da apreensão de todas as estratégias textuais. Para sua caracterização, temo-nos limitado à relação entre repertório textual e sistema de referências, pois, desse modo, se mostra o encaixe do texto em seu ambiente e assim a sua "relação externa". A seleção das normas sociais e das normas literárias se torna a condição para que se constitua a referência correspondente, que de sua parte permite captar a relevância dos elementos captados. Mas as estratégias textuais, antes de tudo, devem organizar as "relações internas", do texto, pelas quais se esboça o objeto estético, o qual se atualizará no ato da leitura.
\end{abstract}

No caso de "beba coca cola", a recepção no plano intraliterário apresenta claras dificuldades iniciais, pelo simples fato de a disposição do poema não se assemelhar à disposição poética tradicional em versos no espaço da página. Ainda assim, e consciente de estar em uma peça vanguardista, o leitor de boa vontade operará a leitura. A possibilidade inicial mais plausível é a apreensão do poema linha a linha, da esquerda para a direita, ou seja, a primeira frase recebida seria "beba coca cola". Nosso leitor, provavelmente, conectará essa mensagem com o slogan publicitário do famoso refrigerante, identificando aí o imperativo "beba" e o substantivo próprio "coca cola". O prosseguimento da leitura se verá condicionado por essa primeira expectativa. O leitor pode esperar, por exemplo, o tema da crítica ao consumismo para o restante da peça poética. A próxima linha traz "babe cola", com um considerável espaço em branco entre as duas palavras. A primeira expectativa pode aí se confirmar. "Babe cola" pode ainda encaixar-se no tema da crítica ao consumismo, numa 

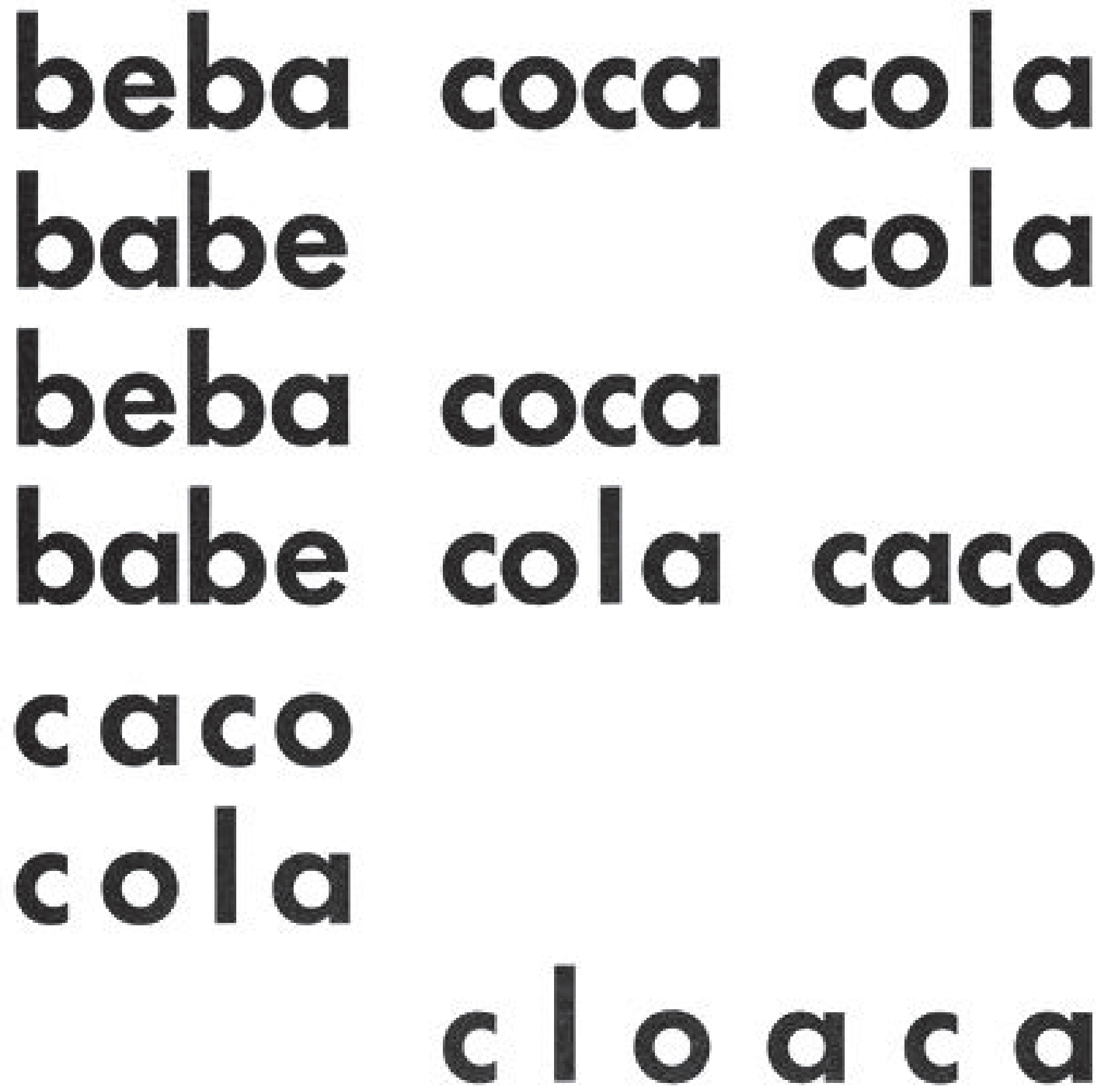
REVISTA DO PROGRAMA DE PÓS-GRADUAÇÃO EM COMUNICAÇÃO, LINGUAGENS E CULTURA DA UNIVERSIDADE DA AMAZÔNIA

possível concretização do verbo "babar" relacionado a algo que não é agradável ao paladar e, por isso, deve ser expelido em forma de baba. A ruptura da expectativa inicial vem na quarta linha. O "babe cola caco" tem o poder de desmontar o tema inicial, originando possivelmente um questionamento na mente leitora. A expectativa sofre uma brusca mudança no meio da obra: agora, o receptor pode se lembrar que se encontra em uma peça vanguardista e que o poema deve ser lido como uma brincadeira e um jogo sonoro e visual. "Babe cola caco", assim como "caco", "cola" e "cloaca", isolados, nas seguintes linhas, trazem ao leitor signos linguísticos que, embora sejam integrais - com significante e significados - parecem não ter nenhum sentido analíticodiscursivo dentro do poema. O leitor, então, em sua busca por formação de sentido, pode voltar ao início da peça, tentando outra leitura. Nesse ponto, sua expectativa em relação ao poema é flutuante. Ele estará aberto a confirmar tanto o tema do consumismo quanto o tema do jogo de palavras. Em uma possível tentativa de leitura vertical, ele lerá "beba babe beba babe caco cola", o que poderia confirmar a intenção paranomásica do poema. Nesse ponto, ele já se verá inevitavelmente preso na estrutura da obra, passando a enxergá-la não somente palavra a palavra, e sim como um todo que pode ter um significado maior. Poderá vislumbrar aí algo como um "cubo mágico", ou cubo de Rubik, onde as palavras são móveis, rotativas e intercambiáveis, cabendo a ele, leitor, manejá-las e dispô-las como melhor lhe aprouver para a busca de formação de sentido. Poderá, assim, realizar a concretização do poema concluindo que ele transmite ao mesmo tempo os dois temas: a crítica ao consumismo e o jogo estético, sonoro e visual.

Ao solicitar tamanha participação do leitor, um poema concreto como "beba coca cola" apresenta delicada recepção. A fragilidade de conexões dadas pelo texto exige um grande trabalho do leitor. A rejeição e o abandono da leitura devem ser considerados, mesmo tratando-se de um leitor ideal, de boa vontade, que, ainda assim, pode deixar o poema com a sensação de fracasso na formação de sentido. Sobre isso já alertavam os concretos em seu manifesto, relembrando a recomendação de Apollinaire de que é preciso habituar-se a apreender de modo sintético e ideográfico, e não somente buscar sentido no analítico e discursivo.

As condições históricas para uma apreensão mais sintética e estética da obra de arte, demandada pelas vanguardas, começam a se desenvolver, segundo Peter Bürger, com a estabilização da classe 
burguesa nas sociedades urbanas mais adiantadas, que criaria leitores mais sensíveis à apreensão estética. Embora saibamos que esse processo histórico-artístico apresenta limitações, é interessante, ainda assim, analisar as palavras de Bürger (2010, p. 27):

\begin{abstract}
Desde meados do século XIX, depois da consolidação do domínio político da burguesia, esse desenvolvimento transcorreu de tal modo que a dialética formaconteúdo nos objetos artísticos começou a se inclinar definitivamente em favor da forma. O conteúdo da obra de arte, sua "mensagem", cede diante do aspecto formal, que se diferencia como estético em sentido estrito. Essa predominância da forma na arte a partir de meados do século XIX pode ser compreendida, a partir da perspectiva da produção estética, como uma disposição sobre os meios artísticos e, a partir da perspectiva da recepção estética, como a focalização na sensibilização do receptor. ${ }^{5}$
\end{abstract}

5 Tradução ao português feita pelo autor deste artigo.
VOL. 16 | N.2 | DEZ.2019 da palavra ISSN 1415-7950

\section{A RECEPÇÃO DO SIGNO LINGUÍSTICO NOS POEMAS FÔNICOS E VISUAIS}

Voltemos a falar do signo linguístico nas peças vanguardistas elegidas para este estudo, apoiando-nos agora em um ponto específico da Teoria do Efeito Estético de Iser (1996). Sabemos que, segundo esse autor, não existe significação sem experiência leitora. Em outras palavras, é a recepção que fundará a significação da obra. O efeito estético, porém, tem uma peculiaridade: ele não depende necessariamente da significação. Quer dizer, o estético não precisa cristalizar-se em algo existente; não tem que fazer referência a nada exterior à obra. Assim, “jolifanto” pode sugerir ao leitor luso-falante o 
significado de "elefante", mas pode também não sugerir significado algum mais além do efeito puramente estético que causa no leitor. O significante "jolifanto" significaria algo que surge no mundo pelo simples efeito estético, e que seria intraduzível e insubstituível por qualquer outro signo linguístico. Seria a inauguração de um significado novo que, no entanto, ainda não poderia ser expresso de outra forma que não a de "jolifanto". O significado pairaria em um plano estético na mente receptora. No caso do receptor proceder à significação por aproximação de "jolifanto" por "elefante", a magia estética seria de certo modo quebrada ao realizar-se a conexão de "jolifanto" com um ente conhecido do mundo real. O fragmento de Iser (1996, Vol. 1, pp. 53-54), a seguir, não se refere diretamente a textos de vanguarda, mas serve como uma luva para nossa análise da recepção dos textos fônicos e visuais e para nossos posteriores comentários. Sobre o efeito estético, diz ele que:

(...) esse efeito só é efeito enquanto o que é significado por ele não se funda em nada senão nele mesmo. Esse efeito, em um primeiro momento, pode ser definido como recusa à categorização ou ainda como uma situação em que o receptor se afasta de suas classificações. Daí segue que devemos substituir a velha pergunta sobre o que significa esse poema, esse drama, esse romance, pela pergunta sobre o que sucede com o leitor quando com sua leitura dá vida aos textos ficcionais. Nesse caso, a significação antes teria a estrutura de um evento; ela mesma é um acontecimento que não pode ser relacionado a denotações de realidades, sejam elas empíricas ou inferidas. Desse modo, no entanto, muda o caráter, ou pelo menos a avaliação da própria significação. Se o texto ficcional existe graças ao efeito que estimula nas nossas leituras, então deveríamos compreender a significação mais como o produto de efeitos experimentados, ou seja, de efeitos atualizados do que como uma ideia que antecede a obra e se manifesta nela.

Retomando "beba coca cola", observamos a seguinte situação: como já dissemos, a peça está composta por signos linguísticos tradicionais, embora em uma combinação pouco comum e, principalmente, em uma disposição espacial que parece convidar ao jogo. A alternativa da leitura signo a signo é plausível e inclusive esperada, mas esse caminho pode interferir no potencial estético do poema. Além disso, ao buscar sentido semântico na peça, poderá suceder na mente receptora a sensação de fracasso e consequente 
abandono de "beba coca cola". Para obter o êxito significativo, o leitor será empurrado a uma apreensão estética, deixando de lado a procura por referentes externos ao poema. A significação da obra seria originada pela disposição espacial, gráfica e fônica dos significantes, e não em seus significados. O sentido da obra está na própria obra em seu contato com o leitor, e não fora dela. A peça cria um mundo inexistente até então, que só se manifesta enquanto efeito estético, por meio da experiência da leitura. A instabilidade dessa recepção estética reside no fato de que, muito facilmente, o receptor buscará sentidos referenciais, o que levaria a recepção estética à falência. Outra possibilidade, bastante provável, é que o leitor flutue entre a recepção estética e a referencial, gerando significados mistos tanto a Karawane quanto a "beba coca cola". Essa opção receptiva pode ser e ter sido realizada pelos públicos conformados nos momentos de lançamento dessas respectivas obras e também pelos receptores atuais. A flutuação nos parece natural. O impacto inicial de Karawane e "beba coca cola" levaria o receptor a uma leitura estética que, em um segundo momento, se mesclaria com a tentativa referencial que, fracassada em grande medida, voltaria a lançar a mente receptora à apreensão estética. A recepção dos poemas de tipo fônico e visual, como estamos vendo, não é simples. Exige do leitor um esforço muito maior quando comparada à recepção de poemas construídos linearmente, com signos tradicionais. Mas ela pode, sim, pese a sua instabilidade, ser realizada com sucesso.

Se voltarmos nossa atenção à concepção de Roman Ingarden (WARNING, 1989, pp. 35-53) quanto à estrutura essencial das obras literárias, aplicada aos nossos objetos de estudo, nos depararemos com outra situação receptiva peculiar. $\mathrm{O}$ estudioso polonês propõe que um texto literário é um esquema composto de estratos identificáveis, dividido em duas dimensões, vertical e horizontal. Interessa-nos aqui debruçarmo-nos principalmente nos estratos verticais, que são os que nos aprofundarão nas relações de contato entre leitor, signo linguístico e formação de sentido das peças de vanguarda. A dimensão vertical estaria formada por quatro estratos: o fonético ou sonoro, o das unidades semanticamente inteligíveis (a partir da conexão significantesignificado), o dos aspectos esquemáticos (a partir da superposição de diversos enunciados) e o das objetividades representadas, que já atuam no campo da projeção das representações mentais sugeridas pelos enunciados. Esses extratos atuam de forma praticamente simultânea 
durante o ato da leitura, em uma conexão interna essencial à unidade formal da obra.

A partir dessa esquematização, Ingarden aborda a questão dos quase-juízos, contrastando o texto literário ao científico. Segundo ele, os enunciados de uma obra científica apresentam juízos genuínos, ou seja, que declaram uma realidade, enquanto a literatura trabalha com os quase-juízos, que apenas sugerem um mero aspecto de realidade, sem, no entanto, chegar a se referirem a realidades autênticas. No caso das vanguardas - questão não mencionada diretamente por Ingarden a montagem se complica. Em "beba coca cola", podemos até imaginar a formação dos quase-juízos, mas em uma experimentação mais extrema, como Karawane, a formação esquemática sugerida pelo polonês não passaria do primeiro estrato (o fonético ou sonoro) e não chegaríamos nem mesmo aos quase-juízos. Ao passarmos ao estrato das unidades semanticamente inteligíveis, a concepção de Ingarden cairia por terra se considerarmos o poema em questão. É como se Karawane transferisse inteiramente ao leitor a responsabilidade de montagem dos demais estratos, o que não ocorre nas obras literárias de arte tradicionais utilizadas pelo pensador polonês como exemplos para suas conclusões estruturais acerca da literatura. No caso dadaísta, os lugares de indeterminação contidos no texto são tantos e tão extensos que a recepção fica em xeque, na dependência de uma enorme carga co-criativa que terá que ser aportada pelo leitor.

Aquilo que Ingarden diz ser uma conexão interna essencial à unidade formal da obra, referindo-se à estrutura estratificada dos textos literários, se perde nos poemas fônicos e em muitos poemas visuais, que trabalham com significantes sem significado imediato. Já vimos, antes, que existe a possibilidade da recepção puramente estética dessas peças vanguardistas. Insistamos um pouco mais nesse tema.

\section{RUPTURA VANGUARDISTA, RUPTURA RECEPTIVA}

Quando falamos de sentido, é normal pensarmos em algo que pode ser explicado com palavras: o sentido de um filme, o sentido de um livro, o sentido de uma frase, o sentido de uma palavra, ou ainda - saindo do campo artístico -, o sentido de uma ação cotidiana, o sentido de uma medida legal, o sentido de uma determinação 
política. Perguntamo-nos constantemente qual o sentido de tudo isso para nós, receptores, e, em geral, conseguimos respostas satisfatórias e explicativas. No entanto, não costumamos aplicar o termo "sentido" para coisas que não podemos verbalizar. Sentados em uma pedra à beira da praia, vendo o sol se pôr detrás das montanhas, qual o sentido disso para nós, receptores? Voltando ao campo artístico: diante de uma obra de Jackson Pollock (LEBRERO STALLS, 2016), não seria raro ouvir de um possível espectador a frase "isso não tem sentido". Mas de que tipo de sentido estamos falando? Qual tipo de sentido esperaria encontrar em Pollock o nosso frustrado espectador? Com essas questões, começamos a entrar no tema do sentido da própria arte. Para nosso estudo, nos interessa tentar entender o que acontece com o conceito da arte a partir das vanguardas. Adorno (2014, p. 10) comenta que:

Ao atacar o que ao longo de toda a tradição lhe parecia
garantido como seu estrato fundamental, a arte se
transforma qualitativamente, se transforma em outra
coisa. A arte é capaz disso porque, em virtude da sua
forma, ao longo dos tempos tanto se dirigiu contra o
meramente existente quanto pediu a sua ajuda, dando
forma aos seus elementos. A arte não se pode reduzir nem
à fórmula geral do consolo, nem à de seu contrário.
A arte tem seu conceito na constelação de momentos que
vão mudando historicamente; nega-se a ser definida. ${ }^{6}$

6 Tradução ao português feita pelo autor deste artigo.
A totalidade do processo da arte e seu desenvolvimento se esclarecem somente no estágio da autocrítica. Só depois da arte se afastar por completo de toda relação com a práxis cotidiana se tornará evidente a progressiva liberação da arte de seus contextos da práxis cotidiana e a diferenciação de um campo específico da experiência (precisamente, a estética) como princípio de 
transformação da arte na sociedade burguesa. ${ }^{7}$

A liberação total da arte dos temas mundanos é algo utópico. Do ponto de vista da produção, o artista estará sempre atrelado ao seu contexto histórico e social, pelo simples fato de existir em uma sociedade e em uma época determinadas, o que transparecerá, de um modo ou de outro, em sua obra. Do lado do receptor, ele também não pode se livrar completamente de sua época para realizar as concretizações. De todo modo, mesmo reconhecendo a impossibilidade da mudança completa do sistema literário - no caminho do referencial ao puramente estético -, é fato que, para receber essa nova literatura, o receptor terá que proceder a um ajuste de sua concepção de sentido. O sentido que buscava nosso receptor de Pollock (2016) citado acima, por exemplo, já não serve para a leitura da vanguarda. A obra de arte de vanguarda, aberta e escancarada à participação do receptor, já não é mais simplesmente obra: é um enigma. A estratégia mental para decifrar esse enigma já não pode ser a de antes. Buscar sentido puramente referencial será dar cabeçadas, uma e outra vez, no portal de entrada à obra. A chave correta passa a ser a da busca de sentido por meio da fruição estética. Há que se deixar enfeitiçar pela proposta da obra. Há que se contornar o caminho consciente e tentar se adentrar na senda inconsciente, atingindo uma apreensão que não se conecta necessariamente com uma compreensão objetiva. Sobre isso, pondera Adorno (2014, p. 166):

\footnotetext{
Por seu caráter enigmático, o próprio compreender é uma categoria problemática. Quem compreende as obras de arte mediante o que elas emanam de consciência não as compreende, e quanto mais compreensão houver, mais intenso é o sentimento de insuficiência, de cegueira no feitiço da arte, ao que se opõe o conteúdo de verdade da arte. (...) Se uma obra se abre por completo, alcança a sua figura interrogativa e se torna necessária a reflexão; então, se distancia e, por fim, volta a assaltar com a pergunta $O$ que é? ao leitor que já se sente seguro. ${ }^{8}$
}

Esse tipo de apreensão de sentido vai mais além daquilo que é considerado normalmente dentro do círculo hermenêutico, em que as partes e o todo se retroalimentam na busca de uma análise satisfatória e de sua consequente formação de sentido. Entre as partes e o todo, e entre o todo e as partes, entram em jogo aspectos incomuns, como
7 Tradução ao português feita pelo autor deste artigo.
8 Tradução ao português feita pelo autor deste artigo. 
a disposição espacial, as tipografias e as sensações acústicas. Nessa recepção, o diâmetro do círculo tende a se ampliar, pois a quantidade de informação estética em seu interior é maior do que a normal. É necessário incluir aí, dentro do círculo, grandes quantidades de informação nãodiscursiva, não-semântica e até mesmo não-linguística, como podem ser os casos das diferentes tipografias em Karawane ou das possibilidades móveis do poema "beba coca cola". Torna-se evidente, então, que a forma é também conteúdo, afirmação que ganha ainda mais força no contexto vanguardista. Assim, ao lado do sentido lógico e racional, se abre a possibilidade de se falar em outro tipo de sentido, o estético. Vanguardas como o dadaísmo, ao realizarem a crítica da instituição arte, derrubam o "nexo fundador de sentido" (ADORNO, 2014, p. 206), chegando a instaurar a própria falta de sentido lógico como um sentido maior em suas peças artísticas, como no caso de Karawane, onde a carência de sentido pode constituir um sentido em si mesmo. O significante "jolifanto" não estabelece nexo algum com significados imediatos. Então, o receptor terá que, primeiro, apreender o sentido da falta de sentido lógico-referencial para, depois, aventurar-se na busca do sentido estético. Tal recepção, uma vez emancipada do sentido racional, terá que se concentrar mais do que nunca nos elementos estéticos da obra. Nosso receptor imaginário de Pollock estaria buscando sentido onde simplesmente não há sentido (e nisso ele teria razão, ao afirmar “isso não tem sentido"). Para lograr a formação de sentido, ele teria que proceder a um giro receptivo, aceitando a falta de sentido referencial como tema da obra e mergulhando em seu sentido estético, muito mais etéreo do que, em um princípio, ele esteve buscando.

A situação de xeque em que se encontra a recepção de algumas obras vanguardistas reside nessa necessidade de abertura receptiva, que pode ou não acontecer, dependendo do perfil sócio-histórico e cultural do grupo de receptores. Peças como Karawane e "beba coca cola" combatem o mecanicismo da leitura tradicional, advogam contra o previsível e, por isso, demandam a aceitação da imprevisibilidade por parte do leitor. A ruptura que propõe a vanguarda literária requer, em igual medida, uma ruptura receptiva, já que o conceito tradicional de nexo nos poemas vanguardistas é tremendamente oscilante, o que pode levar a uma crise interna, durante o ato da leitura, na tentativa de formação de sentido. O puro trabalho estético com a linguagem transforma as obras literárias de vanguarda em um objeto por si só existente, sem - 
ou com poucas - dependências externas: "O que transforma as obras de arte existentes em alguma coisa mais que existência não é algo existente, e sim a própria linguagem" (ADORNO, 2014, p. 144). Elas contêm verdades em si mesmas, aquém de nexos e conexões com o mundo conhecido fora da obra. Esse tipo de arte, que pode vir a ser denominada de hermética, é, na verdade, a partir de nosso ponto de vista, muito mais generosa do que a poesia não-vanguardista, já que propõe um maior número de possibilidades de leitura. Lukács, anos antes do aparecimento da Teoria da Recepção da Literatura e da Teoria do Efeito Estético, já opinava que “As obras de arte ganharam muito mais riqueza e profundidade uma vez findados os tempos supostamente repletos de sentido" (Lukács, citado por Adorno, 2014, pp. 212-213 $)^{9}$. O xeque receptivo nas obras de vanguarda pode ser, ao contrário, dependendo das condições de recepção, somente o início de uma nova partida.

\section{CONSIDERAÇÕES FINAIS}

Comentávamos anteriormente neste artigo acerca da responsabilidade do modelo tradicional de ensino da leitura e da literatura sobre a problemática de recepção de obras literárias que possuem alto grau de intenção estética. Queremos, agora, concluir nosso texto voltando a esse tema e sugerindo uma perspectiva de ensino direcionada a facilitar a apreensão estética de obras literárias. Temos a consciência de que a proposta pode parecer ambiciosa. Vamos, aqui, somente pincelar alguns comentários, com o objetivo de abrir uma nova senda de discussão para futuros artigos.

O texto linguístico - e aqui nos referimos mais que nada ao texto escrito, porém sem excluir totalmente o falado - guarda em si uma contradição: pode ser usado tanto para fins artísticos quanto corriqueiros. Isso quer dizer que, no universo do texto, o estético e o semântico convivem em uma permanente tensão não muito bem resolvida. Em um extremo, poderíamos ter textos como, por exemplo, o do manual de instruções de um forno de microondas. Esse seria o texto corriqueiro, em seu uso quase puramente semântico. $\mathrm{Na}$ outra ponta, podemos tomar um poema concreto, exemplo de texto artístico de predominância estética. Entre o manual do microondas e o poema concreto há um espaço enorme onde poderiam entrar desde
9 Tradução ao português feita pelo autor deste artigo. 
bulas de remédio até a poesia visual cibernética, passando pelos textos jornalístico, publicitário e uma imensa gama de diferentes tipos de comunicação escrita. Elencar toda essa tipologia textual tendo como base diferencial sua intenção estética é um trabalho que está somente em seu ponto de partida e que nos proporemos a desenvolver em outro momento.

Por enquanto, queremos explicitar que a literatura é muitas vezes vítima da má formação de leitores, e que esse é um dos motivos que contribuem para a difícil recepção de textos com grande intenção estética, como são os casos de Karawane e "beba coca cola". Parece-nos natural que, quando aprendemos a ler, nossos professores nos ensinem a desvendar o sentido semântico do texto. Não vemos problema nisso, e esse tipo de aprendizagem será realmente muito útil para a leitura de manuais de microondas e bulas de remédio. Mas será que o aprendizado para ler uma bula é o mesmo necessário para ler um poema? Entre a bula e o poema, o único ponto em comum que vemos é que ambos são objetos formados por letras impressas no papel. Mas a semelhança pára por aí. Há uma discrepância muito grande entre esses dois textos. Um, a bula, é um objeto de índole corriqueira, objetiva, que utiliza o texto para transmitir informação semântica. O outro, o poema, é um objeto de índole artística e subjetiva, que utiliza o texto para transmitir também informação estética. Para ler essa informação estética, é preciso uma mudança de expectativa em relação ao texto, e nós acreditamos que esse câmbio de expectativa deve ser trabalhado desde cedo nos leitores. Quem aprende a ler tem que saber, o quanto antes, que o texto oferece ao receptor outro tipo de formação de sentido que não somente aquela arraigada na informação semântica. Não é pelo simples fato de ter a sua frente um papel com letras impressas que o leitor terá necessariamente que buscar aí uma história, um discurso linear ou um comunicado racionalmente inteligível. O texto é muito mais do que isso, e nossos alunos deveriam ser informados sobre essa questão. Esse tipo de preparo perante o texto não somente facilitaria a leitura de, por exemplo, peças mais ousadas ou vanguardistas, mas também faria com que o receptor tivesse mais possibilidades de sentir a fruição e o prazer estético, aumentando a sua identificação com qualquer tipo de texto literário.

Como promover, dentro das salas de aula, esse ajuste de expectativa é assunto a ser longamente e profundamente discutido com profissionais da Pedagogia. Não nos sentimos aptos, obviamente, 
a encabeçar tão vasta discussão, mas nos parece pertinente deixar aberta essa brecha, que poderia vir a ser desenvolvida a partir daqui.

\section{REFERÊNCIAS}

ADORNO, Theodor. Teoría Estética. Madri: Akal, 2004.

APOLlinAIRE, Guillaume. Calligrammes. Poèmes de la paix et de la guerre. Paris: Rare Books, 1918.

BARTHES, Roland. Elementos de semiologia. São Paulo: Cultrix, 2012.

BÜRGER, Peter. Teoría de la vanguardia. Buenos Aires: Las Cuarenta, 2010.

CONCRETISMO. Disponível em: http://www.horizonte.unam.mx/brasil/ concretismo visualidad/foja31.html. Acesso em: 13 de setembro de 2019.

ISER, Wolfgang. O ato da leitura - uma teoria do efeito estético. São Paulo: Editora 34, 1996 .

JAUSS, Hans Robert. "La historia literaria como desafio a la ciencia literaria". In: La actual ciencia alemana. Seis estudios sobre el texto y su ambiente. Salamanca: Anaya, 1971.

LEBRERO STALS, José (ed.). La energía visible. Jackson Pollock. Una antología. Madri: Antonio Machado Libros, 2016.

POEMAS DO DADAISMO. Disponivel em: https://www.lifeder.com/poemas-deldadaismo/. Acesso em 12 de setembro de 2019.

TORRE, Guillermo de. Historia de las literaturas de vanguardia. Madri: Visor Libros, 1965.

WARNING, Rainer (ed.). Estética de la recepción. Madri: Visor Libros, 1989.

Recebido em 04 Out 2019 | Aprovado em 29 Out 2019

Sérgio Massucci CALDERARO (São Paulo, 1971)

Doutor em Ciências da Informação pela Universidad Complutense de Madrid (UCM), título revalidado pela Universidade de São Paulo (USP) como Doutor em Teoria Literária e Literatura Comparada. Foi professor de Redação Publicitária da Universidade Estácio de Sá (UNESA) e da UCM, além de ter dado aulas de português em empresas, escolas de idiomas e no International College Spain. Foi assistente de Imprensa e Divulgação da Embaixada do Brasil em Madri. É autor de artigos acadêmicos e dos livros A Ilha Urbana e Manual do Futuro Redator. E-mail: sergimas@ucm.es 